\title{
Timothy Larsen John Stuart Mill: A Secular Life (Oxford: Oxford University Press, 2018). Pp.vi + 229. £30:00 (Hbk). ISBN 9780198753155.
}

This excellent book forms part of a series on 'Spiritual Lives'. It is 'a biography of John Stuart Mill' which 'attend[s] to religion' (Larsen (2018) viii). In so doing, Larsen promises to show us 'the Mill you never knew; the Mill that even some of his closest disciples never knew. This is John Stuart Mill, the Saint of Rationalism - a secular life and a spiritual life' (Larsen (2018), viii).

The book more than delivers on this promise. Those not familiar with Mill's life and work will find an excellent introduction to Mill's social milieu, friends, loves, political activity and key works. These are viewed through the lens of Mill's religious thought, but this does not make this biography 'niche': instead, given the compelling case Larsen makes regarding the depth and sincerity of Mill's thinking about, and engagement with, religion from an almost entirely unique (for his period) standpoint of being brought up 'without' religion, this lens gives great insight into the (oftenchallenged) consistency and coherence of Mill's intellectual pursuits, and a thoughtful and nuanced understanding of many of Mill's personal relationships, not least with Harriet Taylor.

Key events and works are dealt with in a scholarly but very accessible way, and lovely vignettes of more personal moments in Mill's life are included. (Most of these are drawn from his often overlooked friendship with Caroline and Barclay Fox - a new personal favourite is Mill making a 'Calendar of Odours' for Miss Fox, so that she could, at any time, 'inhale the fragrances of the specific month which took her fancy' (Larsen (2018), 143).) In this way, the book is both a personal and an intellectual biography. The whole book has an engaging tone - a generous, nuanced and non-judgemental stance is taken, which though not uncritical, yet endeavours to understand, and does so with great empathy. The fact that Larsen manages bring in apt reference to The Princess Bride makes me highly recommend it as an enjoyable read to anyone (Larsen (2018), 81).

For those already familiar with much of Mill's personal life and his key works (and even his lesswell-known works), there is also much to learn and enjoy. Undeniably, the book's greatest strength is Larsen's evident mastery not only of the detail of Mill's engagement with religion (from his father's ordination before Mill's birth, through to his step-daughter's Catholicism, via close friendships with Unitarians, reformist Anglicans, Quakers, and socialists looking to form a 'New Christianity' along the way) but his excellent knowledge, and impressive understanding, of the cultural and religious context in which Mill moved and wrote. This helps put Mill's own theological writings (for instance, the famous pronouncement that if an all-powerful God could send him to Hell for refusing to acknowledge it as 'good', where that word had no connection to what humans mean by 'good', 'then to Hell I will go!') into the context of contemporary religious debate. It also serves to highlight the sincerity of Mill's admiration for Jesus, sometimes seen merely a rhetorical gesture. Lastly, it reveals the consistency of the attitudes revealed in Mill's Three Essays on Religion, which - in turn - casts a new light on his earlier writing.

There is much in this thoughtful engagement with Mill's religious thought and writing - as well as the excellent scholarship on $19^{\text {th }}$-century religious context and theological debates - which should be of interest to the philosopher of religion, particularly the insight provided into Mill's view on contemporary theological debates; his contribution to the ago-old tension between belief in Good's benevolence and His omnipotence; his overall view of the importance, benefits, and status 
of religion; and the Religion of Humanity, especially his belief in humanity's duty to 'co-labour with God to subdue evil and make the world a better place' (Larsen (2018), 201).

There are two further great strengths of the book which make it important for all Mill scholars, not only those interested in Mill's writings on religion and ethics. Firstly, this is the best, most thoughtful, and most nuanced account of Mill's relationship with Harriet Taylor that I have yet read. Larsen is almost unique in taking seriously, and investigating the meaning of, Mill's assertion that Taylor became for him a religion. Even generally 'friendly' accounts of their relationship tend to be embarrassed by Mill's praise of, and mode of writing about, and to, his collaborator, friend, and future wife. They insist we take Mill's praise with a generous pinch of salt - that is, where they don't outright pour scorn on the idea that Taylor could have been anything like the paragon of all the virtues Mill seems to claim.

Larsen takes a refreshing, and illuminating, stance in two ways. Firstly, he takes Mill's assertions at face value, but in a very distinct way. People are being too 'scientific', too literal, about Mill's claims regarding his beloved. Instead, we should take seriously Mill's claim to a religious experience of love. Larsen stands off from making any attempt to verify the truth of Mill's judgements about Taylor - that isn't important. What is important is that 'Mill was being utterly sincere in these statements...The thought really did strike him again and again in wonder and delight that her judgement was perfect, that she inspired all of his best thoughts, and so on' (Larsen (2018), 88). Where others often pause to laugh at Mill, or criticise him for 'idolatry' (or, indeed, read into this some domineering, even dominatrix, element of Taylor's personality, demanding outrageous flattery that Mill could not really have been sincere in providing), Larsen argues:

\footnotetext{
$[1 \mathrm{t}$ would be something of a category mistake to ask whether or not he meant these claims to be taken literally...The real point is this: if he had ever been, he was no longer completely [emotionally] tone deaf; he was no longer fully colour blind. He had heard something, and it was an exquisite sound. He had glimpsed something, and it was a captivating sight. He had a devotional sense. He had Harriet. (Larsen (2018), 88).
}

The objects of many people's devotion can seem to others unworthy, but to focus on assessments of worthiness is to miss the significance of such objects to the people for whom they are supremely important, and thus to miss much of the meaning of their lives (or, at least, much of the meaning as they understood it).

Secondly, Larsen directly rejects those accounts which see something uncomfortable or 'unmanly' in this attitude:

'If you pity Mill for being in this submissive state, you are misunderstanding the situation. It was heavenly bliss. It is vital to grasp how delicious this experience was for Mill...Mill positively revelled in the feeling of being absolutely dependent upon Harriet...he craved the sensation of Harriet being his guide' (Larsen (2018), 85).

It is refreshing to find a biography which takes this element of Mill seriously, and Larsen's understanding of the theological context (e.g. Schleiermacher on religion being 'the feeling of absolute dependence', a theological view Mill's great friend John Sterling had commended to him) means it is treated so as to add to our intellectual understanding of Mill as well as a more personal one. Moreover, where so much writing on Taylor and Mill seems riddled with a misogynist view of women's status and how men ought to view them (and, indeed, any other people), the honest attempt to see things from, and explain them within, Mill's own perspective is an important 
contribution to the field. The book is exemplary in not only not judging Mill for these feelings, but in exploring their significance in a sympathetic way.

Likewise, its treatment of the probability, and plausibility, of Mill and Taylor's relationship being celibate (at least before marriage) is exemplary, not least because it tackles head on the interesting question of why Mill's friends, '[1]ike so many people today, of all the varieties of unruly relationships' which are tolerated, and even celebrated, found 'celibacy to be one of the more outrageous' (Larsen (2018), 114, and see also 79-81). It is interesting that this element of their relationship remains so shocking to modern audiences in a way which an adulterous affair might not be, and refreshing to find an author who does not think it impossible.

Similarly, this book is important to Mill scholarship because of the attention it pays to Mill's relationship with his step-daughter Helen Taylor. Larsen's detailed knowledge of Helen's Catholicism, and therefore use of the Douai-Rheims translations of the Psalms allows him to trace more co-authorship than has previously been acknowledged (Larsen (2018), 163). As there is relatively little on Helen Taylor in print, this book is also a very useful contribution to greater knowledge of her, not only as contributor to Mill's later works, but as a political activist and thinker in her own right.

In structure, the book takes a chronological view of Mill's life. It starts with his father's experiences of religion, and Mill's early life, where there is really excellent discussion of his friendship with sincerely religious Anglican clergymen such as John Sterling and Frederick Maurice, which are often overlooked, as well as his friendship with Thomas Carlyle. In addition, there is an illuminating discussion of Mill's account of his mental 'crisis' (in 1826/27) in the context of how 'conversion' narratives were written by evangelical authors at the same time. Middle chapters deal with his meeting, and relationship, with Harriet Taylor. Later chapters deal with their marriage, and the writing of System of Logic, An Examination of Sir William Hamilton's Philosophy, Principles of Political Economy, On Liberty and Utilitarianism. The end of the book deals with Mill's political career in Parliament (including controversy over his 'atheism'); his relationship with Helen Taylor; and his writing of the Three Essays on Religion. One small criticism is the chapter headings - all quotes from the Bible - which, though apt, tend, I think, to be unclear to a reader not as steeped in these texts as the author; to not be very clear as a guide to chapter contents; and to suggest a deeper religiosity regarding this particular holy text than I think is plausible even from Larsen's own argument.

Sometimes, I think Larsen's point may be stretched too far: people can, for instance, be interested in spirituality, churches, and religious festivals without themselves being 'religious', particularly in a context where the serious ethical thought is being done within a religious society and intellectual milieu. In part, this is, I think, evidenced by Mill's interest in reformist Anglicanism, in Unitarianism, in Free Thinking, and in Quakerism. However, the book's later account is much stronger. The book's final word - taken from the Protestant pastor in Avignon who was a close friend of Mill's and conducted his funeral - that Mill's 'was a soul religious by nature', and that Mill had 'a scepticism which might be called religious' probably best sums up the case.

Larsen paints a detailed, sympathetic and nuanced picture of a deeply thoughtful man who wanted both understanding of ethics and the Divine, and to believe something, but was prevented by his upbringing from starting from a traditional position of faith in a Christian God. That is, Mill's logical and empirical critique of religious belief could not proceed from faith towards either a reformed faith or un-faith (a path more commonly taken and charted) - neither was he able to make the (also common) 'leap' from non-faith to faith through a Damascene conversion. But his 
writing on, and engagement with, religion was much more thoughtful and empathetic than that of many other non-believers (including his teachers and contemporaries, such as Jeremy Bentham), who can dismiss all religion and spirituality as mere superstation or idolatry. As Larsen notes, Mill himself "hauntingly defined "doubt" as "a disposition to believe, with an inability to believe confidently" (Larsen (2018), 206), which well summarises his own position. Larsen's persuasive conclusion is that 'Mills final word on religion' was a 'hopeful, imaginative, beneficial, probabilistic theism' (Larsen (2018), 209): Mill's 'Secular Life' was indeed also a deeply spiritual one.

Helen McCabe, University of Nottingham helen.mccabe@nottingham.ac.uk 